\title{
Population trends of Peregrine Falcon in Northern Spain - Results of a long-term monitoring project
}

\author{
Iñigo Zuberogoitia ${ }^{1,2 *}$, Jon Morant ${ }^{2}$, Iñaki CAstillo ${ }^{2}$, Jose Enrique \\ Martínez $^{3}$, Gorka Burgos², Julen Zuberogoitia ${ }^{2}$, Ainara AzkonA ${ }^{2}$, \\ Julio Ruíz Guijarro ${ }^{4} \&$ Jose Antonio González-Oreja ${ }^{5}$
}

Received: April 26, 2018 -Revised: September 27, 2018 -Accepted: November 23, 2018

This is a contribution submitted to the Proceedings of the World Conference on the Peregrine Falcon in Budapest in September 2017.

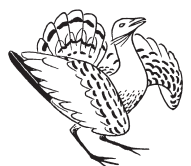

Zuberogoitia, I., Morant, J., Castillo, I., Martínez, J. E., Burgos, G., Zuberogoitia, J., Azkona, A., Guijarro, J. R. \& González-Oreja, J. A. 2018. Population trends of Peregrine Falcon in Northern Spain - Results of a long-term monitoring project. - Ornis Hungarica 26(2): 51-68. DOI: $10.1515 /$ orhu-2018-0015

\begin{abstract}
We monitored Peregrine Falcon (Falco peregrinus) population in Bizkaia, Northern Spain, during two decades (1998-2017). Our population increased from 34 to 47 territorial pairs, as did other European populations until the first years of the $21^{\text {st }}$ century, and then declined until 34 territorial pairs in 2017. The combination of catastrophic events (Prestige oil spill), increasing rain in winter and spring, and direct and indirect mortality factors significantly affected incubation onset, productivity and population stability, which in turn could impact on the floater population. Rain in February significantly affected incubation onset, which showed a slight positive trend during the last decade. Juvenile females laid 12 days later than adults, and each adult female started incubation in the same dates every year. However, the proportion of juvenile females did not significantly increase as might have been expected. Moreover, productivity was inversely related to incubation onset dates. Rain in April and May also affected productivity, and combined with short term extreme weather events determined a decreasing productivity during the last decade. Moreover, apart from human persecution (which caused $40.30 \%$ of the known deaths of Peregrines), we found 18 cases of breeders affected by infectious diseases, also related to weather. The combined effects of these factors, and the low availability of adequate nesting sites, negatively affected (i) territorial populations, (ii) productivity, and (iii) floater population, which in turn also determined territorial population and productivity.
\end{abstract}

Keywords: productivity, population decline, floater population, incubation onset, repeatability, weather

Összefoglalás A vándorsólyom (Falco peregrinus) állományának alakulását két évtizeden keresztül (1998-2017) követtük nyomon Bizkaiaban, Észak-Spanyolországban. Ez idő alatt az állomány 34-röl 47 territoriális párra növekedett, hasonlóan a más európai állományoknál megfigyelt trendekhez, majd 2017-re újra 34 párra csökkent. A növekvő téli és tavaszi csapadék, katasztrófák (pl. Prestige olajkatasztrófa), és a közvetlen és közvetett mortalitási tényezők együttes hatása befolyásolta a költési idő kezdetét, a szaporodási sikert és a populáció stabilitását, ami ennek következtében hatással volt a nem költő állományra. A februári eső jelentősen befolyásolta a kotlás kezdő időpontját, ami az elmúlt időszakban némileg későbbre tolódott. A fiatal tojók 12 nappal később rakták le a tojásokat, mint az adult tojók. Minden egyes adult egyed azonos napon kezdte a kotlást, minden évben. Azonban a fiatal tojók aránya nem nőtt jelentősen, ahogy az várható lett volna. Sőt a költési siker a kotlási időszak eltolódásával ellentétesen alakult. Az áprilisi és májusi eső szintén befolyásolta a költési sikert, és a rövid időtartamú extrém időjárási eseményekkel együtt meghatározta az elmúlt évtized csökkenő tendenciáit. A fő probléma a szándékos pusztítás volt (ami az összes vándorsólyom pusztulás 40,3\%-át okozta). Ezen felül 18 esetet találtunk tenyésztőknél, melyeket fertőző betegségek okoztak, és amiket az időjárás is befolyásolt. Ezen tényezők együttes hatása és a megfelelő fészkelőhelyek alacsony száma negatívan befolyásolta a (i) a territoriális populációkat, (ii) a költési sikert és a (iii) nem költők állományát. 
Kulcsszavak: költési siker, állománycsökkenés, nem-költő (floater) populáció, kotlási időszak kezdete, megismételhetőség, időjárás

${ }^{1}$ Estudios Medioambientales Icarus S.L. C/ San Vicente, 8. $6{ }^{a}$ Planta. Dpto 8. Edificio Albia I. 48001, Bilbao, Bizkaia, Spain,e-mail: zuberogoitia@icarus.es

${ }^{2}$ Department of Ornithology, Aranzadi Sciences Society, Zorroagagaina 11, 20014 Donostia-S. Sebastián, Spain

${ }^{3}$ Bonelli's Eagle Study and Conservation Group, Apdo. 4009, 30080 Murcia, Spain

${ }^{4}$ Departamento Sostenibilidad y Medio Natural. Diputación Foral de Bizkaia. Avda Lehendakari Aguirre, 9-2. 48014 Bilbao, Spain

${ }^{5}$ Facultad de Ciencias Biológicas. BUAP, Benemérita Universidad Autónoma de Puebla. Edificio 112-A, Ciudad Universitaria, 72570 Puebla, Mexico

* corresponding author

\section{Introduction}

Peregrine Falcon (Falco peregrinus) populations increased throughout the 1980s and 1990s in most of their distribution range (White et al. 2013). Once populations reach carrying capacity, which is shaped principally by food and nest substrate availability, it is expected that density-dependent regulation starts to operate on each case (Newton 1998, Bruggeman et al. 2015), although not always is so evident (Wootton \& Bell 2014). Many factors influence population growth, but only density-dependent factors, whose effect increase with crowding, can bring the size of a population under control (Rockwood 2015). As it is often the case, denso-dependent regulations mainly affect productivity and in a lesser extent population growth, which tends to asymptote (see e.g. Heuck et al. 2017). However, denso-dependent factors do not explain per se population declines, and other denso-independent factors usually appear to modulate populations (Monneret et al. 2018). In fact, poisoning by contaminants, increasing of mortality factors and changes in climate conditions affect survival rates of territorial and non-territorial falcons (Zuberogoitia et al. 2006, Smith et al. 2015, Newton et al. 2016). Moreover, most studies on density dependence in animals have focused primarily on the breeding populations, and have generally ignored the possibility that non-breeder mortality has the potential to affect persistence of populations (1) rescuing small populations from extinction by replacing the breeders that die or disperse out of the populations (Kokko \& Shuterland 1998), and (2) buffering the impact of environmental and demographic stochasticity on the viability of the breeding population (Walters et al. 2002, Grimm et al. 2005, Penteriani et al. 2009).

Many populations of territorial species are composed of both territory holders and nonterritorial, usually nonbreeding individuals, commonly defined as 'floaters' (Sergio et al. 2009). Floaters are multifaceted population members that are better understood when considered in three nonexclusive (and frequently interacting) contexts: (1) the ecological scenarios underlying breeding population dynamics; (2) the process of natal dispersal, and (3) the age cohorts contributing to floater pools (Penteriani et al. 2011). Newton (1998) observed that, for Peregrine Falcons, a ratio of one or more floaters to one breeder could be expected for healthy populations, and that larger pools of floaters were associated with more stable breeding populations. However, studying floaters has invariably proven difficult because of their elusive behaviour (see e.g. Bondi et al. 2018), to the point that they have been referred to as a 'shadow' population living in a secretive 'underworld' (see Sergio et al. 
2009). The first indirect evidence for the existence of floaters was the rapid replacement of territorial owners following their experimental removal (Newton 1992).

When mortality is high in floater settlement areas the consequences are diverse. Normally at the beginning of a population decline resulting from a major loss of floaters, the relative stability of breeding performance could generate the false impression that the population is healthy, even if some breeding territories are lost (Penteriani et al. 2011). Additionally, when other factors are combined with floater mortality to reduce the income of individuals to the floating contingent, it may be detected an acceleration rate of population decline due to the lack of individuals to replace the loss of territorial owners.

In the present work we investigate and discuss the demographic trends of a Peregrine population in Bizkaia (Northern Spain). Our study population increased as well as other European populations until the first years of the $21^{\text {st }}$ century (White et al. 2013, Beran et al. 2018), and after that experienced strong decline. Here we show some of the factors explaining this negative trend, and we stress the hidden effect over floater population which actually may be a key argument to explain the observed situation.

\section{Study area}

The study area covered the whole administrative territory of Bizkaia (northern Spain; area $c a$. $2,384 \mathrm{~km}^{2}$; coordinates from $43^{\circ} 11^{\prime} 00^{\prime \prime}$ to $43^{\circ} 12^{\prime} 70^{\prime \prime} \mathrm{N}$ and from $3^{\circ} 12^{\prime} 70^{\prime \prime}$ to $2^{\circ} 13^{\prime} 10^{\prime \prime} \mathrm{W}$ ). The landscape is hilly (50 km separate sea level from the highest altitude, at $1,480 \mathrm{~m}$ a.s.l.) and characterized by the presence of extensive urban and industrialized areas. More than $50 \%$ of the area is dedicated to forestry, at the expense of traditional small-scale farming. The weather is dominated by a wet and warm Atlantic influence and it is included within the rainiest regions of Europe (www.climate-charts.com/World-Climate-Maps.html). The weather is temperate, with an annual rainfall of 1,000-1,300 mm and a mean annual temperature of $11-12{ }^{\circ} \mathrm{C}$ (www.euskalmet.euskadi.eus).

\section{Methods}

The Peregrine Falcon population in Bizkaia was systematically surveyed from 1998 to 2017. In each year we started searching for falcons 30 days before the earliest local laying date recorded for the population ( $20^{\text {th }}$ February, Zuberogoitia et al. 2002). At this time of the season, breeding pairs can be readily detected since they frequently engage in courtship displays, and eyries can be located by observing individuals displaying near the crags and sea cliffs where they will eventually breed. During this period we focused our efforts on identifying adult breeders (Zuberogoitia et al. 2013, Zabala \& Zuberogoitia 2014). Once eggs were laid, we monitored the Peregrine incubation behaviour with telescopes and binoculars. The monitoring points were distant to the eyries (300-1000 m, depending on the surrounding relief and the degree of tolerance to humans) to avoid any undesirable effects of the observer on bird behaviour. In order to gather data on productivity (number of fledglings 
per nesting attempt) and to ring the nestlings, we visited each nesting site at least twice per breeding season, before the young fledged. We first climbed to the eyrie when the nestlings were 20-30 days old (for more details see Zuberogoitia et al. 2013). During the study period we also put a great deal of effort in identifying adult breeders of each territory (for further details see Zuberogoitia et al. 2013, Zabala \& Zuberogoitia 2015).

Incubation onset is a crucial factor in the biology of a species which, usually, does not receive proper attention, perhaps because it is difficult to collate a reliable date of this event. Scientists normally use indirect proxies obtained during nestling monitoring (age of nestling plus 32 days of incubation, see e.g. Zuberogoitia et al. 2002). However, using this method, it results in an overestimation of successful attempts and lack of data regarding those clutches that failed. In order to get a better approximation to incubation onset, we also monitored laying dates and beginning of incubation by direct observation.

Weather data was obtained from three meteorological stations located in the north-eastern coast (Matxitxako), southern mountains (Orozko) and western valleys (Cerroja) which represent climatic variations in the area (www.euskalmet.euskadi.eus). We used the average data of the three stations for each case (rain and number of rainy days per month).

\section{Data analysis}

We ran Generalized Linear Mixed Models (GLMMs) with Gaussian (normal) and Poisson distribution on the response variables. First, we used the incubation onset (normal distribution) as response variable and precipitation and rainy days during February and their interaction as predictive factors; age of females (juvenile or adult) was included as a fixed factor, and year as a random factor. Second, we used the productivity (number of fledglings per territorial pair: 0-4, Poisson distribution) as a response variable to determine the effect of incubation onset dates (predictive variable), considering territory as a random factor. And, third, to compare breeding success from different years while controlling for annual variations in breeding success, a Breeding Quality Index (BQI, normal distribution) was used as the response variable. BQI was calculated as the number of fledglings produced by an animal minus the annual mean of fledglings produced by all the monitored animals the same year (Zabala \& Zuberogoitia 2014, 2015). We used BQI to analyse the effect of precipitation and number of rainy days in April and May and their interactions. To account for possible non-independence relations, territory identity was included as a random factor.

Models were performed through "glmer" and "Anova" functions implemented in the "Ime4" (Bates et al. 2015) and "car" (Fox \& Weisberg 2011) packages for R (R Core Team 2015).

We used one-way ANOVA entering female as a factor to determine if incubation onset dates of each female resembled each other more than they did the overall population. Further, we calculated repeatability as described by Lessels and Boag (1987) and calculated standard errors associated with the repeatability as described by Becker (1984). Repeatability is the fraction of behavioural variation that is due to differences between individuals. Formally, repeatability $(r)$ is the variance among individuals and $\mathrm{s}^{2}$ is the variance within individuals over time. Behaviours that show relatively low within-individual variance compared to high among-individual variance are more repeatable. In other words, when individuals 


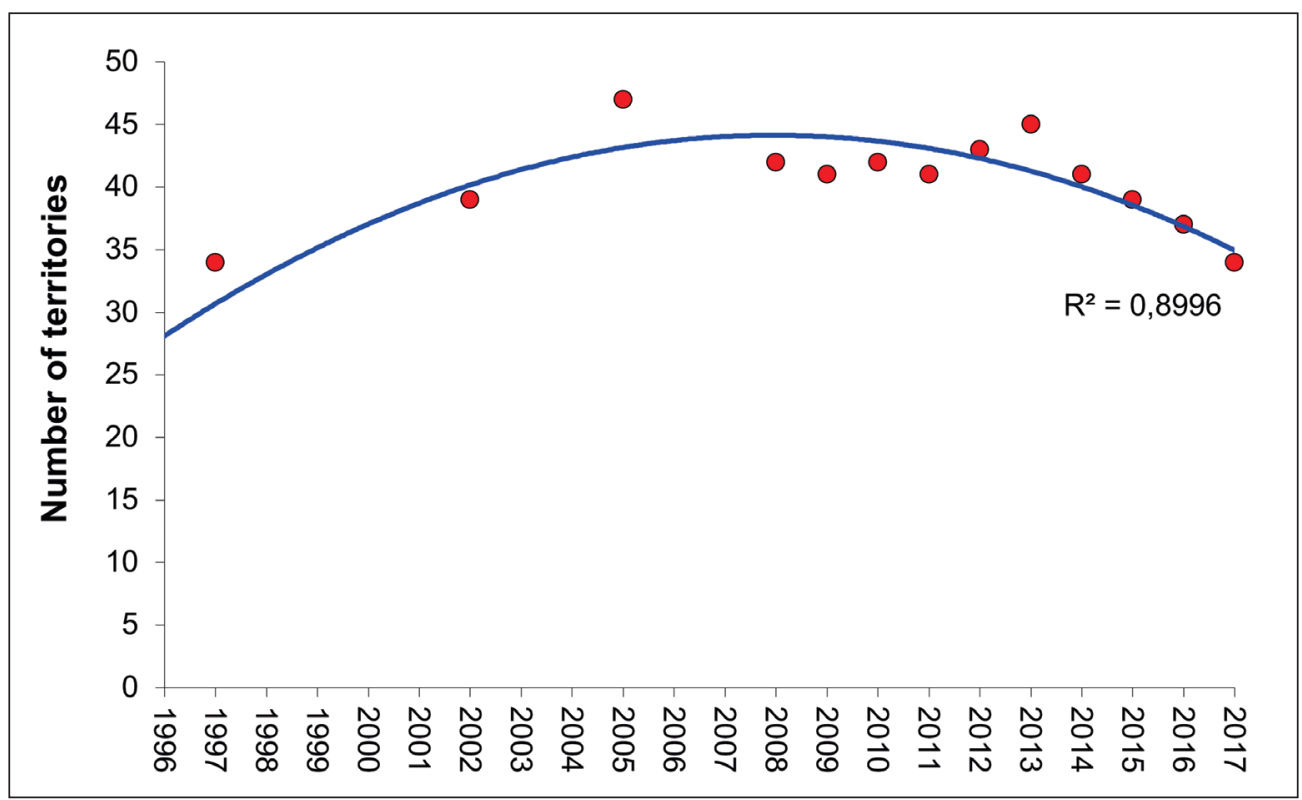

Figure 1. Population trend of Peregrine Falcon in Bizkaia, Northern Spain, during the study period (1997-2017)

1. ábra A vándorsólyom populáció alakulása a vizsgálati időszakban (1997-2017) Bizkaia, ÉszakSpanyolország területén

behave consistently through time and when individuals behave differently from each other, then the behaviour is repeatable (Bell et al. 2009).

Mean values have been reported with $( \pm)$ the standard deviation. Statistical significance was set at $\mathrm{P}<0.05$.

\section{Result and Discussion}

\section{Population trend}

When we started to monitor the Peregrine population we found 34 territorial pairs, just the same number than 21 years later. The population grew steadily to 47 territorial pairs (2005), following the recovery of the population over the European's range (see White et al. 2013) and later started a slight decline until 2017 (Figure 1), as occurred also in other European populations (Kéry et al. 2018, Monneret et al. 2018, Prommer \& Bagyura 2018).

\section{Reproductive parameters and factors affecting them}

Productivity of Peregrine Falcons followed a negative trend $\left(\mathrm{R}^{2}=0.59\right.$, productivity $=$ $-0.08 *$ year +2.47 ) (Figure 2). This figure was gradually affected by different factors where some of them hide the effect of others. 


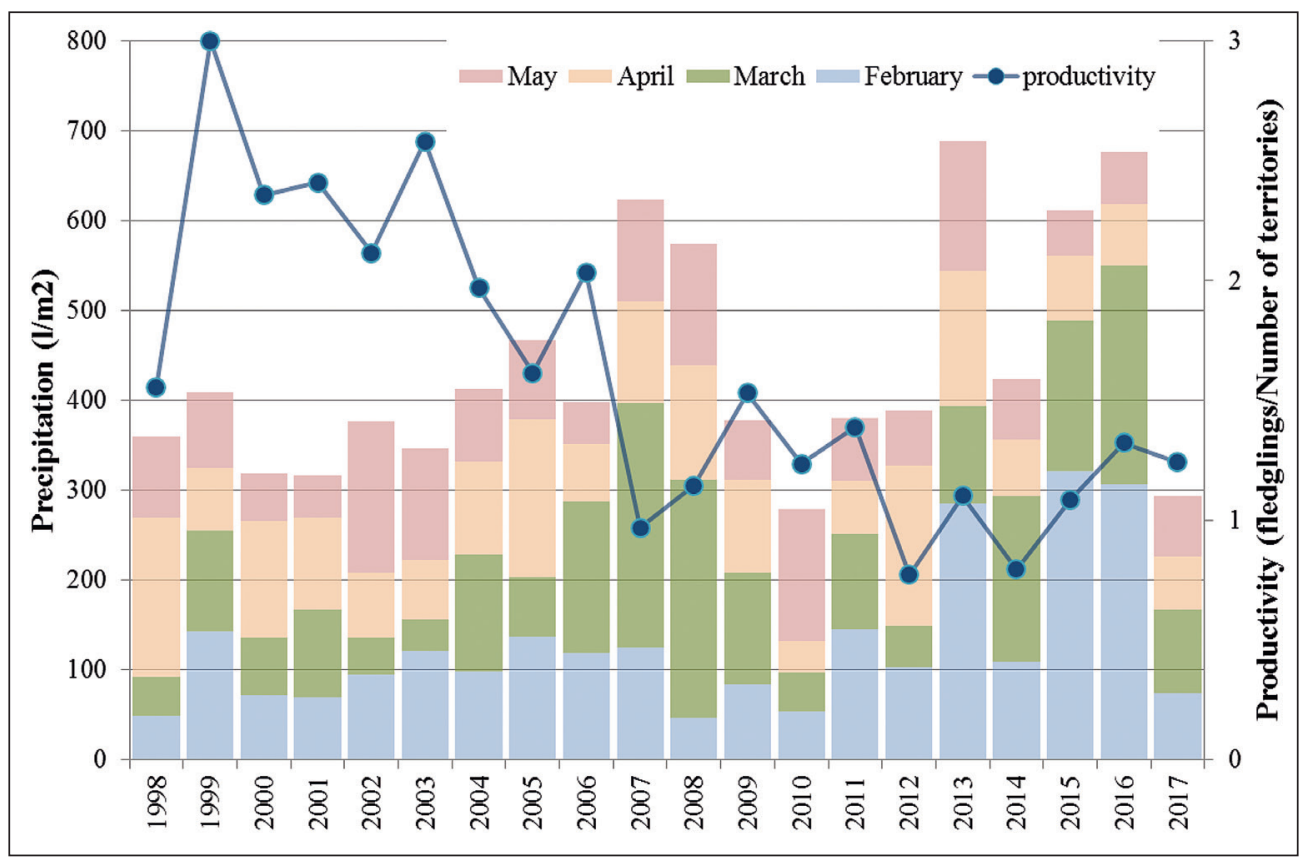

Figure 2. Productivity of Peregrine Falcons and cumulated precipitation during the breeding seasons (February-May) in Bizkaia, Northern Spain, during the study period (1998-2017)

2. ábra A vándorsólymok produktivitása és a csapadék megoszlása a költési időszakban (februármájus) Bizkaiaban, Észak-Spanyolországban, a vizsgálati időszakban (1998-2017)

\section{Catastrophic events}

On the $13^{\text {th }}$ November 2002, the tanker Prestige sunk off La Coruña (NW Spain) and provoked an oil spill that affected the whole of the Cantabrian Coast and the Southwest of France, including our study area. An undetermined number of adults was affected by lethal oil concentrations through eating polluted prey, increasing the turnover rate of territorial adults from $22 \%$ (before Prestige) to $30 \%$ (Zuberogoitia et al. 2005). Moreover, at the same time, an unknown proportion of the Peregrine Falcons carried sub-lethal levels of pollutants which caused breeding disorders. On the one hand, an evident effect was the loss of clutches, mainly during incubation, due to the death of females and to failures caused by high levels of polycyclic aromatic hydrocarbons in the eggs which killed embryos (Zuberogoitia et al. 2005). On the other hand, the bioaccumulation of pollutants caused even more serious long-term effects, affecting the reproductive capacity of males and females which remained in the territory. Further, some sterile birds also remained in the territory during several years, affecting the medium-term productivity rate.

The effect of this catastrophic event was buffered due to the combination of both relative dry springs in the following years, which favored the productivity rate, and previous high reproductive seasons (Figure 2), that produced a large number of floaters. However, we did not know the proportion of floater population affected by lethal and sub-lethal pollution 
Table 1. Results of GLMM to evaluate the effect of precipitation (rainfall and number of rainy days and their combined effect) and age of females on the incubation onset of Peregrine Falcons in Bizkaia during the study period (1998-2017). The values of the estimator, standard error, the $z$ value and its corresponding P value probability are shown. Significant values are highlighted in bold

1. táblázat Az általánosított lineáris kevert modell eredményei a csapadék hatásának elemzésére (eső és esős napok száma, illetve ezek együttes hatása), és a vándorsólyom tojók életkora a kotlás kezdetén Bizkaiaban, a vizsgálati időszak alatt (1998-2017). A táblázat a paraméterbecslést, a standard hibát, a z és a P értékeket mutatja. A szignifikáns értékek félkövéren szedettek

\begin{tabular}{|l|c|c|c|c|}
\hline \multicolumn{1}{|c|}{ Values } & Estimator & St Error & $\boldsymbol{z}$ & $\boldsymbol{P}$ \\
\hline Intercept & $\mathbf{1 9 . 2 8}$ & $\mathbf{4 . 7 2}$ & $\mathbf{4 . 0 8}$ & $<\mathbf{0 . 0 0 1}$ \\
\hline Factor (female age) juvenile & $\mathbf{1 1 . 3 0}$ & $\mathbf{2 . 3 6}$ & $\mathbf{4 . 7 9}$ & $<\mathbf{0 . 0 0 1}$ \\
\hline Rainfeb & $\mathbf{- 0 . 0 3}$ & $\mathbf{0 . 0 5}$ & $-\mathbf{0 . 6 8}$ & $\mathbf{0 . 0 1 5}$ \\
\hline Dayfeb & -0.26 & 0.27 & -0.95 & 0.89 \\
\hline Rainfeb* Dayfeb & 0.003 & 0.002 & 1.13 & 0.26 \\
\hline
\end{tabular}

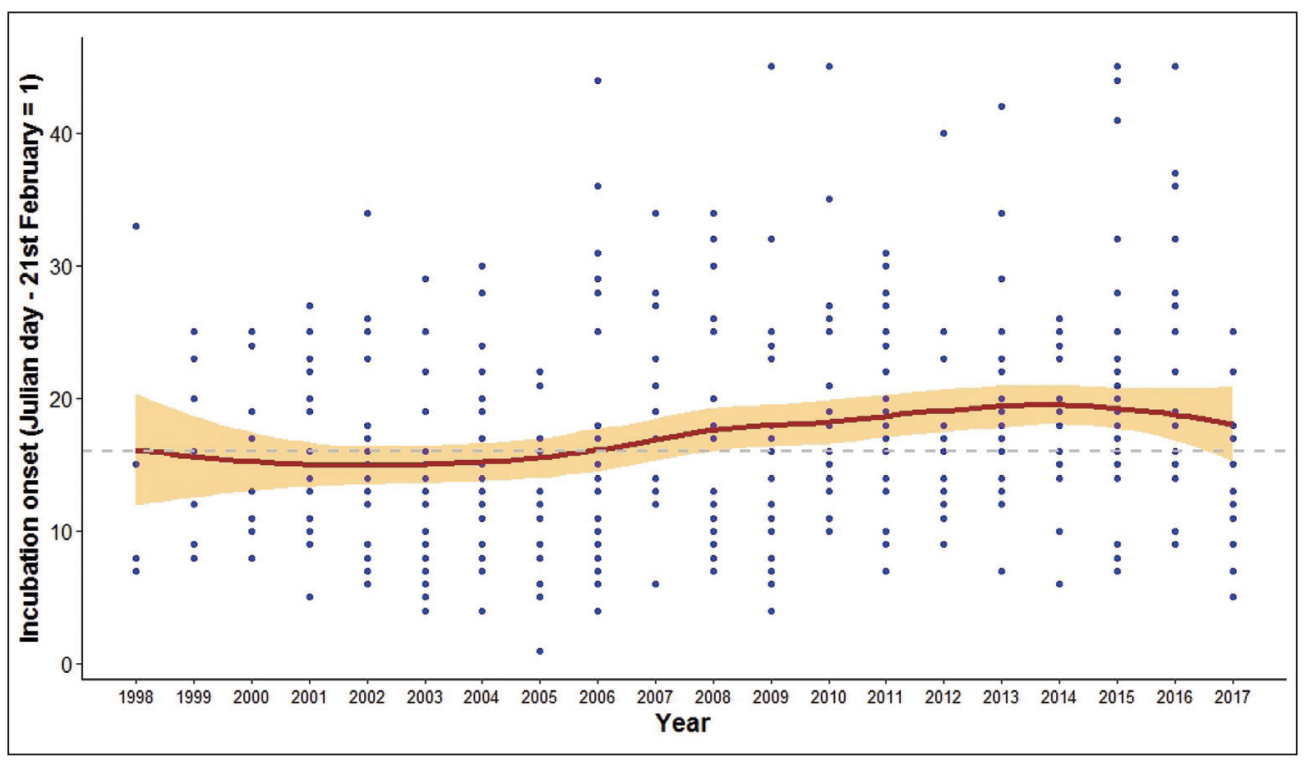

Figure 3. Incubation onset of Peregrines in Bizkaia, Northern Spain, during the study period (19972017). Dates were transformed to Julian dates, being $21^{\text {st }}$ February the first day (the earliest incubation onset). Average dates (line) and standard error (shaded area) are represented using a smoothed curve. Dashed line refers to $16^{\text {th }}$ day

3. ábra A vándorsólymok kotlási dátumainak eltolódása Bizkaia, Észak-Spanyolország területén a vizsgált időszakban (1997-2017). A dátumok a Juliánusz-naptár alapján módosított értékek, vagyis február 21 a kezdő dátum (a legkorábbi eltolódás). Az átlagos dátumokat vonal, míg a standard hibát árnyékolt terület jelzi. A szaggatott vonal a 16. napnak felel meg 
effects, although we suspect that it might have been high, if we consider the effect observed on territorial falcons.

\section{Late winter weather conditions and incubation onset}

The incubation onset of Peregrines showed a slight ascendant trend during the last decade (Figure 3). In a first sight, this seems to be due to a direct relationship with rain in February that affects dates of incubation onset (Table 1). Winter weather also determines breeding phenology of Peregrines and their prey species in other latitudes (Bruggeman et al. 2015). However, this factor alone does not explain the observed constant trend of delaying dates. It may be expected that incubation onset is affected by the combined effect of other parameters. For example, juvenile females started incubation on average 12 days later than adults (Table 1, Figure 4). Juvenile females lay eggs later than adults due to a delayed maturation (Deeming 2002).

Incubation onset strongly depends on individuals. Females laid clutches approximately in the same dates every year (Table 2). The average range of variability on the laying dates was $13 \pm 8.05$ days in the study area. Our study suggests that the laying date may be a heritable trait of females, although our estimate of repeatability (0.53) indicates that current heritability may be affected by external factors. Intra-individual variability was linked with factors related

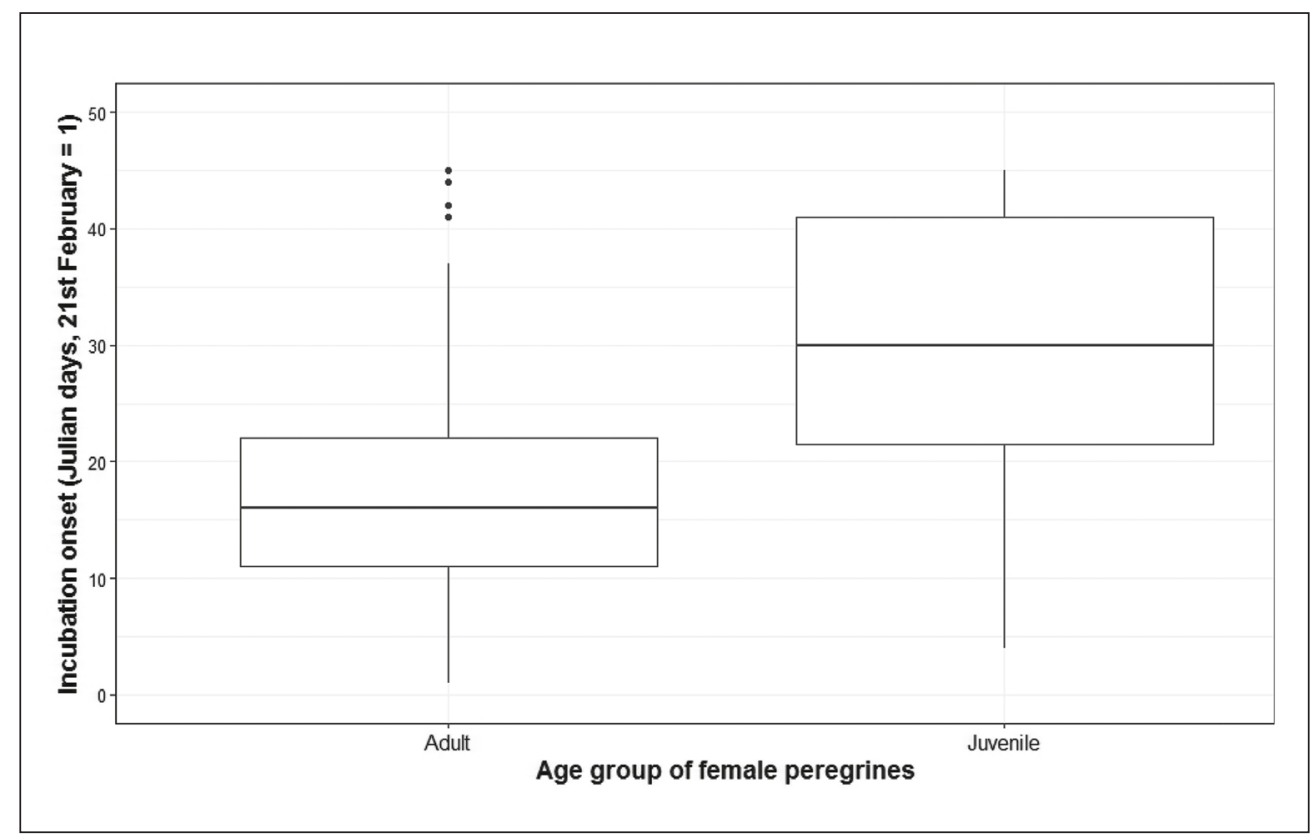

Figure 4. Boxplot showing differences between the incubation onset of adult and juvenile females of Peregrine Falcon in Bizkaia during the study period (1998-2017). Dates were transformed to Julian dates, being $21^{\text {st }}$ February the first day (the earliest incubation onset)

4. ábra A kotlás idejének eltolódásában megmutatkozó különbség öreg és fiatal tojók esetében a vizsgálati időszakban (1998-2017) Bizkaiaban. A dátumok a Juliánusz-naptár alapján módosított értékek, vagyis február 21. a kezdő dátum (a legkorábbi eltolódás) 
Table 2. Results of date repeatability analysis of the incubation onset of Peregrine Falcon in Bizkaia (1998-2017), considering first the same female and second the same territory but changing the female

2. táblázat $A$ vándorsólyom költések dátum-eltolódásainak ismételhetőségi elemzésének eredményei Bizkaiaban (1998-2017). Az első esetben ugyanaz a tojó, míg a második esetben ugyanaz a terület, de más tojó figyelembe vételével

\begin{tabular}{|l|c|c|c|c|c|}
\hline & Ri & SE & F & df & P \\
\hline Same female & 0.53 & 0.47 & 3.26 & 212 & 0.000 \\
\hline Changing female & 0.11 & 0.89 & 1.238 & 89 & 0.239 \\
\hline
\end{tabular}

to the change of mate that always caused delayed laying dates, or body condition of the female (pers. observ.). However, when we analysed repeatability considering the change of the females of each territory, we obtained a very low repeatability index $(0.11$, juvenile females were not considered in the analysis), which reinforced our previous remark on heritability.

During the first decade of our study, females kept the average incubation onset below the $16^{\text {th }}$ Julian day, but after the declining of the productivity the incubation onset started to delay due to the incorporation of new females that laid eggs later than previous ones.

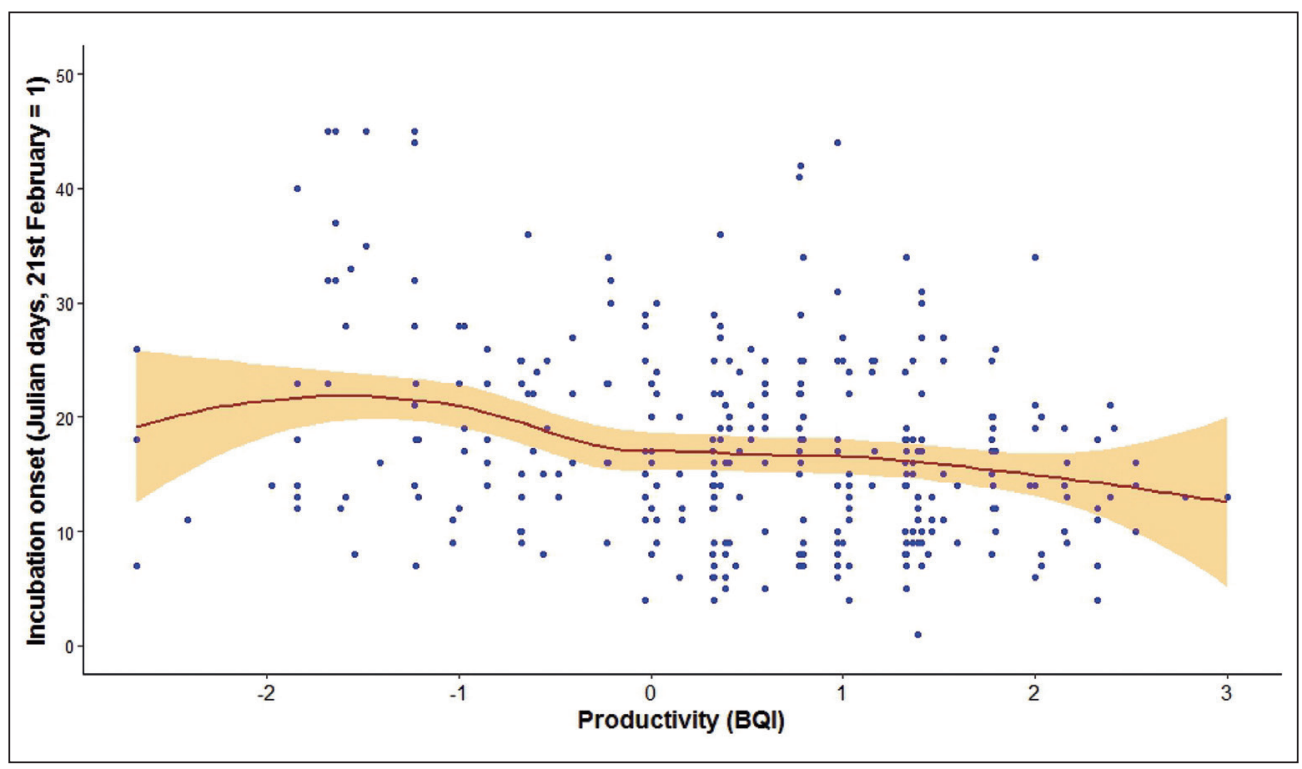

Figure 5. Relationship between productivity, measured as Breeding Quality Index (BQI), and the laying dates of Peregrines in Bizkaia, Northern Spain, during the study period (19982017). Dates were transformed to Julian dates, being $21^{\text {st }}$ February the first day (the earliest incubation onset). Average (line) and standard error (shaded area) are represented using a smoothed curve

5. ábra A produktivitás és a mért költés minőségi index (Breeding Quality Index, BQI) kapcsolata, kiegészítve a vándorsólymok tojásrakási dátumaival Bizkaiaban (Észak-Spanyolország), a vizsgálati időszakban (1998-2017). A dátumok a Juliánusz-naptár alapján módosított értékek, vagyis február 21. az kezdő dátum (a legkorábbi eltolódás). Az átlagos dátumokat vonal, míg a standard hibát árnyékolt terület jelzi 
As expected, productivity was inversely related to incubation onset dates (GLMM, Estimate $=-0.036, \mathrm{SE}=0.007, \mathrm{t}=-4.95, \mathrm{P}<0.001)$ (Tapia \& Zuberogoitia 2018). However, the low value of the estimate is due to high variability in the results (Figure 5). This variability is conditioned by other factors as weather during incubation and nestling raising phases.

\section{Juveniles as breeders}

During the study period we detected 36 yearling (second calendar year) females in the monitored population (Figure 6). High number of juvenile Peregrines trying to nest implies a high turnover rate due to an increase in breeder mortality (Zuberogoitia et al. 2009).

Zabala and Zuberogoitia (2015) showed that yearling females were significantly worse breeders than adults. On the one hand, our results suggest that what makes the difference is not breeding experience or age but maturity, since we found no evidence of reduced success in first time adult breeders. On the other hand, according to Altwegg et al. (2014), observed survival estimates showed high juvenile mortality, with survival probability soaring to $\approx 0.75$ in the second year and increasing slightly to $\approx 0.79$ in older birds. These estimations suggest a strong selection against low quality Peregrines in the first year of life, before the breeding season begins. Therefore, we suggest that the yearling females occupying a territory could be highly successful birds and that territorial and mating displays could be accelerating the maturation process. More interesting is the fact that, with equal survival probabilities for adult breeders and breeding yearlings, individuals that start to breed as yearlings are likely to have a higher lifetime breeding success rate than other birds (Zabala \& Zuberogoitia 2015).

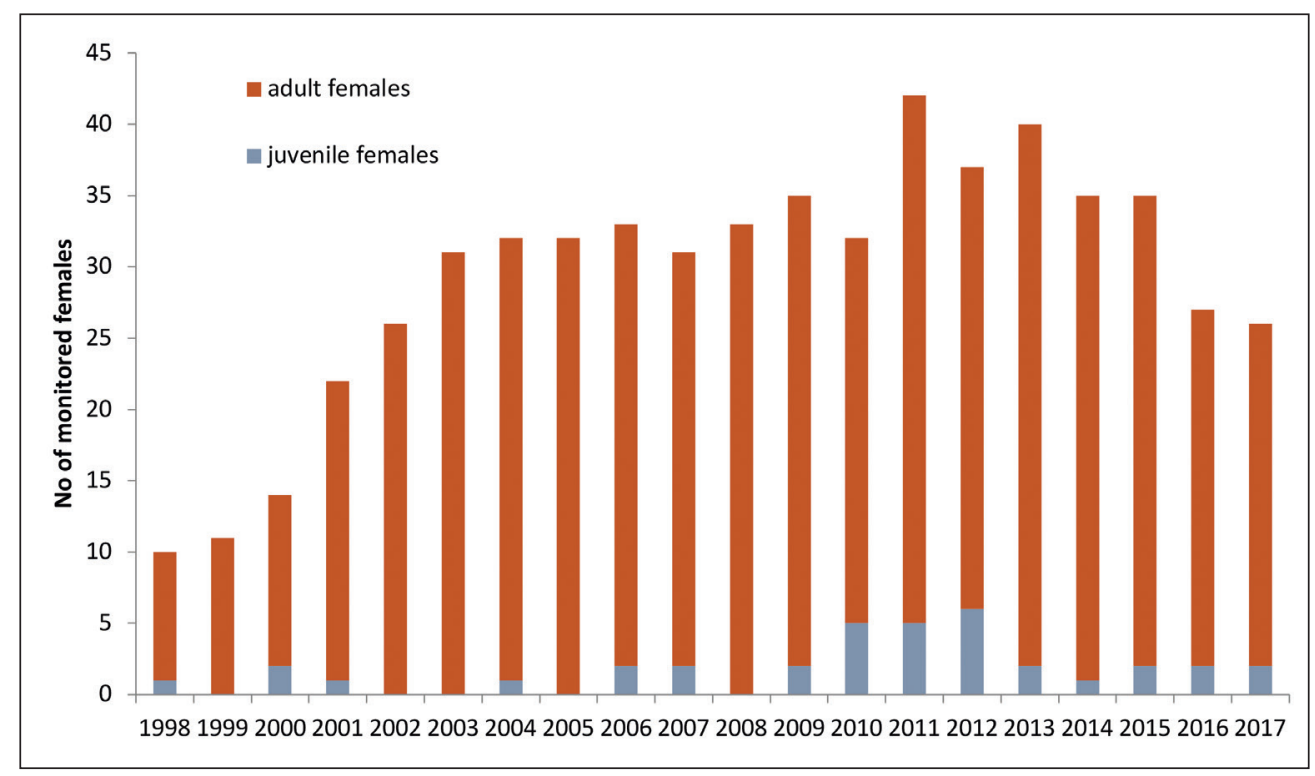

Figure 6. Number of juvenile and adult females in the monitored breeder populations of Peregrine Falcons in Bizkaia during the study period (1998-2017)

6. ábra A fiatal és öreg tojók száma a megfigyelt vándorsólyom populációban Bizkaiaban a vizsgálati időszakban (1998-2017) 
Simultaneously, during the study period we only found five yearling breeding males. Two of them did not breed in their first attempt and disappeared, another did not breed in the first year but he did in the subsequent years. The fourth started the breeding season but failed during the laying process, and the fifth male paired in the 2015 breeding season with a fourth calendar year female. They successfully raised two fledglings out of three hatched chicks.

\section{April and May rainfall}

Zuberogoitia et al. (2015) proved that low April rainfall significantly increased productivity in our study area. The amount of precipitation and duration of rain affected nestlings during their first weeks of life. The affection was different considering eyrie quality and shelter capacity (Zuberogoitia et al. 2015), as it has also been reported in other regions (Bruggeman et al. 2015). However, the effect of April rainfall on nestling survival varied during the last years due to observed delayed reproduction of Peregrines (see below) and strong effects of short term extreme weather events.

Productivity, considering the whole study period (1998-2017) was negatively affected by rain in April and the combination of amount of precipitation and number of rainy days of April, but also the combination of rain in April and May and the number of rainy days in April and May (Table 3). However, the low value of the estimates suggests that the effect could be masked by other factors not considered in this analysis.

During the last years we detected strong effects of episodic weather events on nestling survival, which agrees with Anctil et al. (2013) and Carlzon et al. (2018). For example, the

Table 3. Results of GLMM to evaluate the effect of precipitation (rainfall and number of rainy days and their combined effect) during April and May on the Breeding Quality Index (BQI) of Peregrine Falcons in Bizkaia during the study period (1998-2017). The values of the estimator, standard error, the $z$ value and its corresponding $P$ value probability are shown. Significant values are highlighted in bold

3. táblázat Az általánosított lineáris kevert modell eredményei az április és májusi csapadék (csapadék mennyisége és az esős napok száma, valamint ezek kombinációja) a vándorsólyom költés minőségi indexére (Breeding Quality Index, BQI) gyakorolt hatásának becslésére, Bizkaiaban, a vizsgálati időszakban (1998-2017). A táblázat a paraméterbecslést, a standard hibát, a z és a P értékeket mutatja. A szignifikáns értékek félkövéren szedettek

\begin{tabular}{|l|c|c|c|c|}
\hline \multicolumn{1}{|c|}{ Values } & Estimator & St Error & $\boldsymbol{z}$ & $\boldsymbol{P}$ \\
\hline Intercept & 2.78 & 2.01 & 1.28 & 0.20 \\
\hline Rainapril & $\mathbf{0 . 0 5}$ & $\mathbf{0 . 0 1}$ & $\mathbf{3 . 7 9}$ & $<\mathbf{0 . 0 0 1}$ \\
\hline Rainmay & 0.01 & 0.01 & 1.60 & 0.11 \\
\hline Dayapril & -0.1 & 0.11 & -1.53 & 0.13 \\
\hline daymay & $\mathbf{- 0 . 4 6}$ & $\mathbf{0 . 1 4}$ & $\mathbf{- 3 . 3 3}$ & $<\mathbf{0 . 0 0 1}$ \\
\hline Rainapril:rainmay & $\mathbf{- 0 . 0 1}$ & $\mathbf{0 . 0 0}$ & $\mathbf{- 3 . 9 4}$ & $<\mathbf{0 . 0 0 1}$ \\
\hline Dayapril:daymay & $\mathbf{0 . 0 2}$ & $\mathbf{0 . 0 0}$ & $\mathbf{3 . 2 6}$ & $\mathbf{0 . 0 0 1}$ \\
\hline Rainapril:dayapril & $\mathbf{- 0 . 0 1}$ & $\mathbf{0 . 0 0}$ & $\mathbf{- 3 . 5 7}$ & $<\mathbf{0 . 0 0 1}$ \\
\hline Rainmay:daymay & 0.00 & 0.00 & 1.27 & 0.20 \\
\hline
\end{tabular}


spring of 2017 was being dry (Figure 2) and the breeding success of Peregrines was high. However, a polar cyclone affected the study area during the last week of April. There was a combined effect of low temperatures that dropped close to $0{ }^{\circ} \mathrm{C}$, winds over $80 \mathrm{~km} / \mathrm{h}$ and strong precipitations (over $20 \mathrm{l} / \mathrm{m}^{2}$ in two days; www.euskalmet.euskadi.eus). In a period of five days we detected the die of all the nestlings of ten eyries out of 23 monitored nesting events. Most of the affected cases were related with exposed eyries, but not all, and unlikely some exposed eyries survived. The cyclone differentially affected the nestlings according to their age. Most of the affected nestlings were between 10 and 20 days old, whereas nestlings younger than 10 days and older than 20 days survived. Little nestlings were covered by their mothers, keeping warm and dry conditions, and nestlings over 20 days were able to thermoregulate and they were also attended by their parents. However, nestlings between 10 and 20 days old do not thermoregulate yet and their size caused that females were not able to cover them completely, which caused a continuous loss of heat and the progressive weakening occurred.

Similar events also occurred, for instance in the third week of April 2012, when the study area was strongly affected by an extra-tropical cyclone (which was called "Petra"), and during the second week of April 2016 or the last week of April 2014. All of these particular adverse weather events caused significant declines in the productivity of Peregrines (Figure 2). Hence, the impact of weather in few days hides the above mentioned relationship between productivity and monthly weather statistics, making it the most difficult to find a significant relationship.

\section{Mortality causes}

The main cause of mortality of Peregrine Falcons in our study area was direct persecution (Table 4). Actually, killing is still the first cause of death for birds of prey in Spain (Real et al. 2001, Martínez et al. 2006, 2016, González et al. 2007, Margalida et al. 2008). Notwithstanding their protected status, Peregrines are intentionally shot every year, even during the breeding season. Direct persecution has a double effect. First, productivity is affected due to the death of territorial birds and its effect related to the differential quality and experience of new breeders respect to older birds which stay in the same territory for years (Zabala \& Zuberogoitia 2014). Second, direct persecution affects both territorial falcons and floaters. Therefore, floater population is reduced due to (1) direct mortality, (2) a lower than expected number of incomers, because of reduced productivity, and (3) the number of floaters that enter in empty territories. The floating population could become exhausted through increased recruitment to the breeding population (Franklin 1992).

Con-specific attacks during territorial conflicts caused six known deaths in our study population $(8.96 \%$ ) (Table 4). This cause is not normally considered in scientific publications but it should be taken in mind for future researches. Killing by other Peregrines may be an important denso-dependent factor regulating populations.

Mortality caused by diseases is also difficult to monitor because weak birds normally die in cliffs, far from people. During the study period we collected eight dead Peregrines with evident signs of disease and starvation (Photo 1). The first record was found during the 
Table 4. Causes of death of Peregrine Falcons in Bizkaia, Northern Spain, during the study period (1998-2017). Information about the number of affected Peregrines, considering the gender, and how many of them died is also attached for "disease"

4. táblázat $A$ vándorsólyom pusztulás okai a vizsgálati időszakban (Bizkaia, Észak-Spanyolország). A „betegségek" kategória esetén az érintett egyedek száma, neme és a pusztulások száma részletezve

\begin{tabular}{|c|c|c|c|c|c|}
\hline Causes of death & $\mathbf{N}$ & Percentage (\%) & & & \\
\hline Shoot & 27 & 40.30 & & & \\
\hline \multicolumn{3}{|l|}{ Collision } & & & \\
\hline Electric line & 5 & 7.46 & & & \\
\hline Fence & 3 & 4.48 & & & \\
\hline Wind mill & 2 & 2.99 & & & \\
\hline Others & 8 & 11.94 & & & \\
\hline Electrocution & 3 & 4.48 & & & \\
\hline Disease & 8 & 11.94 & & $\mathrm{~N}$ of cases & Mortal consequence \\
\hline Drowned & 2 & 2.99 & Females & 10 & 2 \\
\hline Oil & 1 & 1.49 & Males & 8 & 6 \\
\hline indet? & 2 & 2.99 & & & \\
\hline Peregrine attack & 6 & 8.96 & & & \\
\hline total & 67 & & & & \\
\hline
\end{tabular}

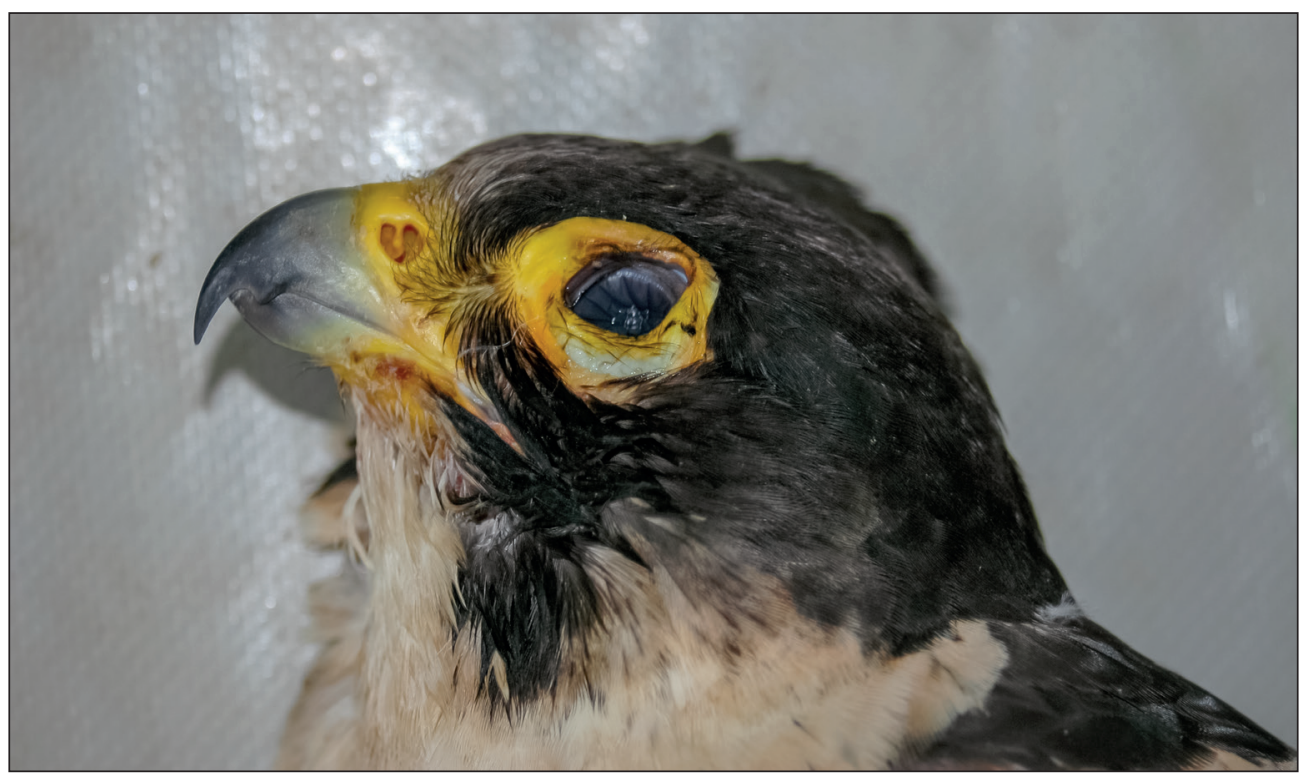

Photo 1. Male breeder dead due to infectious disease. It results evident the effect of swollen and lachrymose eyes. In fact, orbital cerum was broken due to the amazing swollen. @ P Photo credit: Iñigo Zuberogoitia

1. fotó Egy fertőző betegségben elpusztult költő hím. Ennek egyértelmű jele a duzzadt és csipás szem. ๑ Fotó: Iñigo Zuberogoitia 


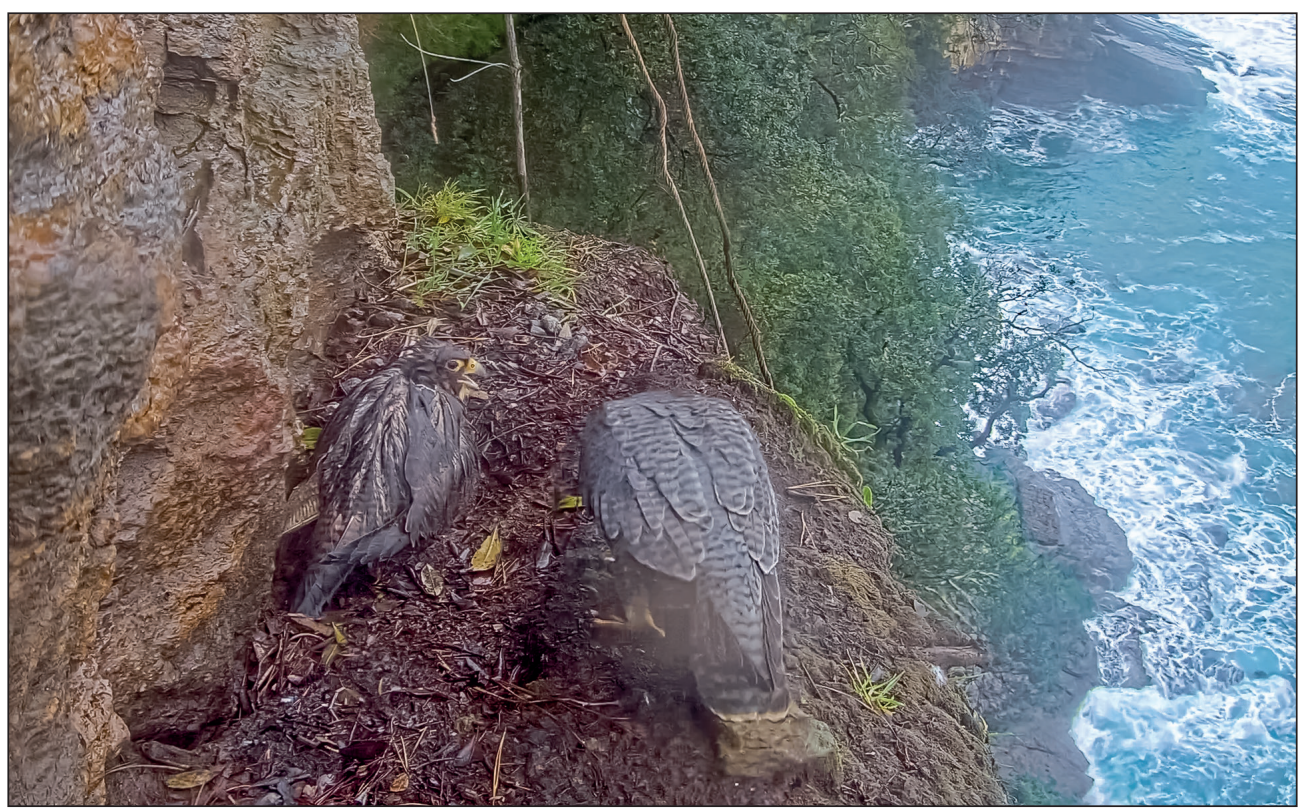

Image 2. The female (right), dry, came to the eyrie to relieve the male, that was totally drenched. Male was incubating eggs during intense rain while female was resting in a shelter place, recovering after suffering the same situation. ( ) Photo credit: Avis Producciones

2. fotó A tojó (jobb oldalon) száraz, épp akkor érkezett a fészekhez, hogy segítsen a hímnek, aki addigra teljesen elázott. A hím heves esőben kotlott a tojásokon, amíg a tojó ugyanebből a helyzetből regenerálódott egy védett helyen. @ Fotó: Avis Producciones

rainy, breeding season of 2007, when some territorial Peregrines appeared with clear symptoms of being suffering a fatal disease (Zuberogoitia 2010). Affected Peregrines showed swollen and lachrymose eyes and apathetic behaviour. It seems that in those wet and cold breeding seasons the disease was more virulent and affected more individuals. Females were first affected while incubating eggs or little nestlings. Our hypothesis here is that during adverse weather conditions females must spend more energy heating eggs and nestlings and they become weaker because of the contact between the incubating patch and wet substrates. During the first days the eyes of the affected females started to swell up until they were almost closed. Although females still incubated, males had to invest more time and effort incubating and feeding females and nestlings (Photo 2). During the last years we detected ten females with evident signs of this disease, from which two died or at least suddenly disappeared (carcasses were not found). The other $80 \%$ survived thanks to male care. The other side of the coin was that while males attended females, they (males) were infected with the disease. Not all were severely infected, but we detected eight cases (some, but not all, of them were paired with previously affected females) in which males suffered the same symptoms. In such cases males were not able to hunt and stayed by their females. Six of the affected males (75\%) disappeared. Therefore, in addition to habitual mortality causes, hidden infectious diseases could be behind the adult turnover rate. 


\section{Other problems}

We have to consider also the loss of breeding sites caused by human activities. The main factor was the alteration of old abandon quarries, albeit the knowledge of the problem and the protection status of the species (Castillo et al. 2008). In the last years we have registered the actual loss of five territories after actuations to filling abandon quarries.

\section{Conclusion}

Our results reveal that Peregrine Falcons in our study area are suffering a combined effect of different factors affecting finally to the population structure. One of the main factors is the weather conditions during the last weeks of winter, before the laying dates, and during incubation and nestling raising period. This factor negatively affected productivity, but also adult survival due to higher prevalence of fatal diseases during rainy springs. This, in turn, caused low numbers of juveniles incoming to the floater population due to such a low productivity. Peregrines could be "trying to correct" the negative effect of adverse weather, delaying incubation onset. We suspect that the observed trend in laying dates might be an adaptive response of the population, since some late breeders could be recompensed with higher breeding success.

Floaters occupy territorial vacancies after the death of owners. The changeover rate also increased after catastrophic events (Zuberogoitia et al. 2009) and due to other mortality causes. However, the reduction of floater population is becoming evident since some vacancies are not covered by new birds, mainly in low quality territories which finally disappear (Penteriani et al. 2005).

In summary, the combined effect of rainy events during winter and springs, direct and indirect mortality factors, and reduced availability of adequate nesting sites, affects (1) territorial populations, (2) productivity and (3) floater population, which in turn determine territorial population and productivity.

\section{Acknowledgements}

We thank L. Astorkia for field assistance. This research was partially funded by the Dpto Sostenibilidad y Medio Natural of the Diputación Foral de Bizkaia. All the necessary permits were issued by the Agriculture and the Environment Departments of the Diputación Foral de Bizkaia. In memory of Mikel Larrea. 


\section{References}

Altwegg, R., Jenkins, A. \& Abadi, F. 2014. Nestboxes and immigration drive the growth of an urban Peregrine Falcon Falco peregrinus population. - Ibis 156: 107-115. DOI: 10.1111/ibi.12125

Anctil, A., Franke, A. \& Bêty, J. 2013. Heavy rainfall increases nestling mortality of an arctic top predator: experimental evidence and long-term trend in Peregrine Falcons. - Oecologia 174: 1033-1043. DOI: 10.1007/s00442-013-2800-y

Bates, D., Maechler, M., Bolker, B., Walker, S., Christensen, R. H. B., Singmann, H. \& Rcpp, L. 2015. Package 'lme4'. - R Foundation for Statistical Computing, Vienna

Becker, W. A. 1984. A manual of quantitative genetics. - Pullman, Washington: Academic Enterprises

Bell, A. M., Hankinson, S. J. \& Laskowski, K. L. 2009. The repeatability of behavior: a meta-analysis. - Animal Behaviour 77: 771-783. DOI: 10.1016/j.anbehav.2008.12.022

Beran, V., Vrána, J. \& Horal, D. 2018. Population trends and diversification of breeding habitats of Peregrine Falcon (Falco peregrinus) in the Czech Republic since 1990. - Ornis Hungarica 26(2): 121-129. DOI: 10.1515/orhu-2018-0020

Bondì, S., Guzzo, E., Mascara, R. \& Sarà, M. 2018. Onset of natal dispersal in Peregrine Falcon from Mediterranean islands (Italy). - Ornis Hungarica 26(2): 201-221. DOI: 10.1515/orhu-2018-0029

Bruggeman, J., Swem, T., Andersen, D., Kennedy, P. \& Nigro, D. 2015. Dynamics of a recovering Arctic bird population: The importance of climate, density dependence, and site quality. - Ecological Applications 25(7): 1932-1943. DOI: 10.1890/14-1591.1

Carlzon, L., Karlsson, A., Falk, K., Liess, A. \& Møller, S. 2018. Extreme weather affects Peregrine Falcon (Falco peregrinus tundrius) breeding success in South Greenland. - Ornis Hungarica 26(2): 38-50. DOI: 10.1515/orhu-2018-0014

Castillo, I., Elorriaga, J., Zuberogoitia, I., Azkona, A., Hidalgo, S., Astorkia, L., Iraeta, A. \& Ruiz, F. 2008. Importancia de las canteras sobre las aves rupícolas y problemas derivados de su gestión [Influence of quarries on the cliff-nesting birds and management implications]. - Ardeola 55(1): 103-110. (in Spanish)

Deeming, D. C. (ed.) 2002. Avian incubation. Behaviour, environment, and evolution. Oxford Ornithology Series. - Oxford University Press, Oxford

Fox, J. \& Weisberg, S. 2011. An $\{$ R $\}$ Companion to Applied Regression, $2^{\text {nd }}$ ed. - Thousand Oaks CA: Sage. URL: http://socserv.socsci.mcmaster.ca/jfox/Books/Companion

Franklin, A. B. 1992. Population regulation in Northern Spotted Owls: theoretical implications for management. - In: McCullough, D. \& Barret, R. (eds.) Wildlife Populations. - Elsevier, London, pp. 815-827.

Grimm, V., Revilla, E., Groeneveld, J., Kramer-Schadt, S., Schwager, M., Tews, J., Wichmann, M. \& Jeltsch, F. 2005. Importance of buffer mechanisms for population viability analysis. - Conservation Biology 19: 578-580. DOI: 10.1111/j.1523-1739.2005.000163.x

González, L. M., Margalida, A., Mañosa, S., Sánchez, R., Oria, J., Molina, J. I., Caldera, J., Aranda, A. \& Prada, L. 2007. Causes and spatio-temporal variations of non-natural mortality in the vulnerable Spanish Imperial Eagle Aquila adalberti during a recovery period. - Oryx 41: 1-8. DOI: 10.1017/S0030605307414119

Heuck, C., Hermann, C., Schabo, D. G., Brandi, R. \& Albrecht, J. 2017. Density-dependent effects on reproductive performance in a recovering population of White-tailed Eagles Haliaeetus albicilla. - Ibis 159: 297-310. DOI: 10.1111/ibi.12444

Kéry, M., Banderet, G., Neuhaus, M., Weggler, M., Schmid, H., Sattler, T. \& Parish, D. 2018. Population trends of Peregrine Falcon in Switzerland with special reference to the period 2005-2016. - Ornis Hungarica 26(2): 91-103. DOI: 10.1515/orhu-2018-0017

Kokko, H. \& Sutherland, W. J. 1998. Optimal floating and queuing strategies: consequences for density dependence and habitat loss. - American Naturalist 152: 354-366. DOI: 10.1086/286174

Lessels, C. M. \& Boag, P. T. 1987. Unrepeatable repeatabilities: a common mistake. - Auk 104: $116-121$. DOI: $10.2307 / 4087240$

Margalida, A., Heredia, R., Razin, M. \& Hernández, M. 2008. Sources of variation in mortality of the Bearded Vulture Gypaetus barbatus in Europe. - Bird Conservation International 18: 1-10. DOI: 10.1017/ S0959270908000026

Martínez, J. A., Martínez, J. E., Mañosa, S., Zuberogoitia, I. \& Calvo, J. F. 2006. How to manage human-induced mortality in the Eagle Owl Bubo bubo. - Bird Conservation International 16: 265-278. DOI: $10.1017 /$ S0959270906000402 
Martínez, J. E., Zuberogoitia, I., Jiménez-Franco, M. V., Mañosa, S. \& Calvo, J. F. 2016. Spatio-temporal variations in mortality causes of two migratory forest raptors in Spain. - European Journal of Wildlife Research 62: 109-118. DOI: 10.1007/s10344-015-0981-x

Monneret, R-J., Ruffinoni, R., Parish, D., Pinaud, D. \& Kéry, M. 2018. The Peregrine population study in the French Jura mountains 1964-2016: use of occupancy modeling to estimate population size and analyze site persistence and colonization rates. - Ornis Hungarica 26(2): 69-90. DOI: 10.1515/orhu-2018-0016

Newton, I. 1992. Experiments on the limitation of bird numbers by territorial behaviour. - Biological Reviews 67: 129-173. DOI: 10.1111/j.1469-185X.1992.tb01017.x

Newton, I. 1998. Population Limitation in Birds. - Academic Press, London

Newton, I., Mcgrady, M. J. \& Oli, M. K. 2016. A review of survival estimates for raptors and owls. - Ibis 158: 227-248. DOI: $10.1111 /$ ibi.12355

Penteriani, V., Ferrer, M. \& Delgado, M. M. 2011. Floater strategies and dynamics in birds, and their importance in conservation biology towards an understanding of nonbreeders in avian populations. - Animal Conservation 14: 233-241. DOI: 10.1111/j.1469-1795.2010.00433.x

Penteriani, V., Otalora, F., Ferrer, M. \& Delgado, M. M. 2009. When individuals senesce: the 'Florida effect' on stable populations of territorial, long-lived birds. - Oikos 118: 321-327. DOI: 10.1111/j.16000706.2008.17190.x

Penteriani, V., Otalora, F., Sergio, F. \& Ferrer, M. 2005. Environmental stochasticity in dispersal areas can explain the 'mysterious' disappearance of breeding populations. - Proceedings of the Royal Society B 272(1569): 1265-1269. DOI: 10.1098/rspb.2005.3075

Prommer, M. \& Bagyura, J. 2018. Review of the development of the Peregrine Falcon (Falco peregrinus) population in Hungary between 1997 and 2018. - Ornis Hungarica 26(2): 2-11. DOI: 10.1515/ orhu-2018-011

R Development Core Team 2015. R: A Language and Environment for Statistical Computing. Vienna: R Foundation for Statistical Computing, http://wwwRprojectorg/

Real, J., Grande, J. M., Mañosa, S. \& Sánchez-Zapata, J. A. 2001. Causes of death in different areas for Bonelli's Eagle Hieraetus fasciatus in Spain. - Bird Study 48: 221-228. DOI: 10.1080/00063650109461221

Rockwood, L. 2015. Introduction to population ecology, $2^{\text {nd }}$ ed. - Wiley-Blackwell, Oxford

Sergio, F., Blas, J. \& Hiraldo, F. 2009. Predictors of floater status in a long-lived bird: a cross-sectional and longitudinal test of hypotheses. - Journal of Animal Ecology 78: 109-118. DOI: 10.1111/j.13652656.2008.01484.x

Smith, G. D., Murillo-Garcia, O. E., Hostetler, J. A., Mearns, R., Newton, I., McGrady, M. J. \& Oli, M. K. 2015. Demography of population recovery: survival and fidelity of Peregrine Falcons at various stages of population recovery. - Oecologia 178: 391-401. DOI: 10.1007/s00442-014-3168-3

Tapia, L. \& Zuberogoitia, I. 2018. Breeding and nestling biology of raptors. - In: Sarasola, J. H., Grande, J. M. \& Negro, J. J. (eds.) Birds of Prey: Biology and Conservation in the XXI century. - Springer International Publishing, DOI: 10.1007/978-3-319-73745-4

Walters, J. R., Crowder, L. B. \& Priddy, J. A. 2002. Population viability analysis for Red Cockaded Woodpeckers using an individual-based model. - Ecological Applications 12: 249-260. DOI: 10.2307/3061150

White, M. C., Cade, T. J. \& Enderson, J. H. 2013. Peregrine Falcons of the world. - Lynx Edicions, Barcelona

Wootton, J. T. \& Bell, D. A. 2014. Assessing predictions of population viability analysis: Peregrine Falcon populations in California. - Ecological Applications 24: 1251-1257. DOI: 10.1890/13-1323.1

Zabala, J. \& Zuberogoitia, I. 2014. Individual quality explains variation in reproductive success better than territory quality in a long-lived territorial raptor. - PLoS ONE 9(3): e90254. DOI: 10.1371/journal. pone. 0090254

Zabala, J. \& Zuberogoitia, I. 2015. Breeding performance and survival in the Peregrine Falcon Falco peregrinus support an age-related competence improvement hypothesis mediated via an age threshold. - Journal of Avian Biology 45: 141-150. DOI: 10.1111/jav.00505

Zuberogoitia, I. 2005. Halcón peregrino (Peregrine Falcon) - Falco peregrinus. - In: Carrascal, L. M. \& Salvador, A. (eds.) Enciclopedia Virtual de los Vertebrados Españoles. - Museo Nacional de Ciencias Naturales, Madrid http://www.vertebradosibericos.org/ (in Spanish)

Zuberogoitia, I. 2010. País Vasco. - In: del Moral, J. C. (ed.) El halcón peregrino en España. Población en 2008 y método de censo [Peregrine Falcon in Spain. Population in 2008 and census methods]. - SEO/ BirdLife, Madrid, pp. 150-164. (in Spanish) 
Zuberogoitia, I., Azkona, A., Zabala, J., Astorkia, L., Castillo, I., Iraeta, A., Martínez, J. A. \& Martínez, J. E. 2009. Phenotypic variations of Peregrine Falcon in subspecies distribution border. - In: Sielicki, J. \& Mizera, T. (eds.) Peregrine Falcon Populations. Status and Perspectivas in the $21^{\text {st }}$ century. - Turul Publishers \& Poznań University of Life Sciences Press, Warsaw - Poznań, pp. 295-308.

Zuberogoitia, I., Martínez, J. A., Iraeta, A., Azkona, A., Zabala, J., Jiménez, B., Merino, R. \& Gómez, G. 2006. Short-term effects of the prestige oil spill on the Peregrine Falcon (Falco peregrinus). - Marine Pollution Bulletin 52: 1176-1181. DOI: 10.1016/j.marpolbul.2006.02.016

Zuberogoitia, I., Martínez, J. E., González-Oreja, J. A., Calvo, J. F. \& Zabala, J. 2013. The relationship between brood size and prey selection in a Peregrine Falcon population located in a strategic region on the Western European Flyway. - Journal of Ornithology 154: 73-82. DOI: 10.1007/s10336-012-0872-9

Zuberogoitia, I., Martínez, J. E. \& Zabala, J. 2013. Individual recognition of territorial Peregrine Falcons Falco peregrinus: a key for long-term monitoring programmes. - Munibe 61: 117-127.

Zuberogoitia, I., Ruiz Moneo, F. \& Torres, J. (eds.) 2002. El Halcón Peregrino [The Peregrine Falcon]. - Servicio Publicaciones de la Diputación Foral de Bizkaia, Bilbao (in Spanish)

Zuberogoitia, I., Zabala, J., Martínez, J. E. \& Olsen, J. 2015. Alternative eyrie use in Peregrine Falcons: is it a female choice? - Journal of Zoology 296: 6-14. DOI: 10.1111/jzo.12221

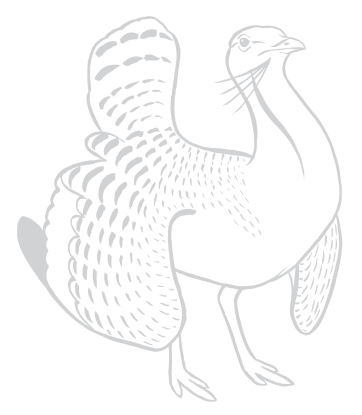

